\title{
The Influence of English Movies on English Listening Teaching in College
}

\author{
SHI Xi-chun, CHEN Meng-jie \\ Changchun University, Changchun, China
}

\begin{abstract}
Listening, in language teaching, is a skill that requires active engagement. To help their students become effective listeners becomes one of the great challenging tasks for the language teachers. In the Chinese contexts, this challenge is greater for college English teachers, for listening skills, an important part of communication skills, have not been given as much attention as reading or writing skills in teaching non-English majors, especially a decade ago. This paper introduces English movies on English listening teaching in college, and puts forward some application strategies of English movies in English listening teaching.
\end{abstract}

Keywords: English movies, English learning, listening

\section{Introduction}

English movies, acquiring a variety of information, such as the image, text, animation, etc., have gained an important role in college English listening teaching by its unique advantages. At the same time, English movies have become an effective teaching method in English listening. The introduction of English movies to English listening teaching can improve students' learning interest, expand their knowledge, and improve their listening ability, thus promoting the level of listening teaching. Therefore, college English teachers should fully integrate the teaching resource, and bring more English movies to classroom.

\section{English Movies Help Stimulate Students' Thirst for Knowledge and Improve Their Learning Enthusiasm}

Interest is the best teacher. When a person is interested in something, he will have a huge power to understand it, and further grasp it. So we must take all possible means to stimulate students' interest in learning, so as to improve their listening by mobilizing their enthusiasm. Interest of study includes two kinds, namely direct interest and indirect interest. Among them, direct interest comes from the learning process, while the indirect interest from the study purpose. Direct interest will reinforce the interest of learning, and reduce the burden of learning and psychological pressure of students; indirect interest is to enhance the students' learning perseverance and confidence in their learning. Both direct interest and indirect interest are not born, but are formed by the cultivation of the day after tomorrow. Interest arises from the emotion,; it is difficult to produce a

SHI Xi-chun, lecturer, master, Public Foreign Language Teaching and Research Department, Changchun University. CHEN Meng-jie, lecturer, master, Public Foreign Language Teaching and Research Department, Changchun University. 
strong interest in something in the lack of real environment of the emotional development. Art is the best bridge of emotional communication, especially in English listening learning. English movies is the creation of life, which has an obvious effect on the emotional change.

The story, rich, colorful pictures, and actor's emotion in the English movie can stimulate students' learning enthusiasm than the boring English teaching materials, as well as improve their learning enthusiasm. When students have a strong interest in English movies, they will be interested in the language in movies, which further stimulate students to imitate and pursue the passion for film language.

\section{English Movies Help Adjust the Classroom Atmosphere}

English is our second language; in the process of listening training, we should maximize the mobilization of positive factors, and reduce the impact of adverse factors. If a student is in a helpless and passive state when learning, there must exist some obstacles, and the learning effect is definitely unsatisfactory. Especially not too much of the resources can be used in listening course, classroom teaching will go into a dead end simply listening to the tape recorder for a long time. Besides that, the whole classroom atmosphere will also become very awkward, and the teacher-student relationship will appear a rift. To let students speak English and be willing to speak English, teachers must establish a harmonious relationship between them. Thus, open the students' hearts, promote them to enter into the activities of oral dialogue through their own enthusiasm to infect students. As one of the important media showing the Western cultures, English movies suppress sweep classroom atmosphere in traditional class, bring more happiness to students, and achieve the combination of listening teaching and practical application, which greatly improves the communicative competence of students. The famous English film Kramer vs. Kramer, for example, brings everyone to a real and flesh family scene with tears and laugher; students' mood varies with changes in the story. In the face of Joanna' leaving, they feel difficult to understand; in the face of Ted, they feel helpless; in the face of Billy, they have a kind of sympathy and compassion. The plot of the film really goes into students' heart, which creates more common language between students and students, as well as students and teachers.

\section{English Movies Provides a Real Learning Environment by Reproducing the Real Language Scene}

The study without learning environment is blind and invalid. It is of great importance for students to feel problems, put forward problems, and solve problems in the study of college English listening. The creation of ineffective scenario makes students have a sense of boredom and boredom, which affects the quality and level of English listening teaching. In college English teaching, the creation of situational teaching can fully tap the initiative and creativity of student, as well as improve their interest of classroom teaching. The traditional listening teaching mainly relies on the repeated learning of the listening material, and there is no real teaching situation. While the most important of language learning is the perfect combination of teaching theory and language environment, only in a real environment can students not help thinking of the relevant language, and use the language of the association right. Language learning lack of real environment can not be avoided in the end of the small alley of mute English. The information provided by English movies is European and native language, whose artistic conception is quite rich and flexible. In that case, students attracted gradually in the plot 
of the story, imitate the hero in tone unconsciously, just like going into a vivid English scenes, which lays a solid foundation for English learning. The language environment provided by the famous English movie "nuclear boat storm", whose theme focus on sea battle, is real and vivid. The sharp language style of Colonel Ramsey, the helpless and anger of Colonel Hunter both creates a real language learning environment for students. In particular, the infective and impactive film plots make students learn more effective learning close to the reality language, and enhance their understanding of language and memory.

\section{English Movies Provide Students With a Broad Space to Listening and Speaking}

English is a kind of arts about language, as well as a professional course. Since it is language, surely is practical, which needs to open the mouth to speak. At present, the study of English in junior high school is mostly mute English serving for the examination oriented education. It is important to improve the level of college English teaching and the quality of oral English teaching and listening teaching. There is no shortcut to language learning, if so, it must be listening and saying. The language in the movies comes from life, which is the reprocessing of life language. On one hand, watching English movies and repeatedly listening to the dialogue can open up the vocabulary of students, so that students can easily remember more practical words; on the other hand, they also cultivate their sense of language and improve their information sensitivity. English movies reappear the real life, learning, and life scenes in its full implementation of the story, will not let the students feel tired and boring, but stimulate their morale, which provides more choices for the students' oral expression.

\section{English Movies Help Dig Cultural Connotation and Improve Students' Intercultural Communication Ability}

Under the influence of American structuralism, the content of English teaching limits the language system itself, such as vocabulary, grammar, sentence structure, and so on. At the same time, the purpose of English learning is only developing students' English ability, thus language is regarded as a independent system regardless of cultural background. Under the influence of this kind of teaching mode, basic English education and non-professional college English education in China generally put focus on the cultivation of examination ability, resulting in a huge difference of written test and interview scores. Besides that, high score low-energy phenomenon is particularly serious, and intercultural communication process is full of loopholes, unable to meet the requirements of countries on the application of communicative language talent and quality education philosophy. Language reflects culture and culture should be expressed in language. The process of language communication is a process of cultural collision and fusion. The difference between Eastern and Western culture is so big that if we do not pay attention to cultural differences, there will be communication barriers and embarrassment in language communication, which restricts the further development of intercultural communication. English movies are a mirror showing the foreign culture, also a bridge between culture and communication culture, as well as a reflection of cultural model, habits of thinking, way of life, concentration of customs, and cultural history of a nation. Bringing English movies to listening teaching can help students have a broad understanding of western culture, social system, customs, historical figures, and meet their curiosity of Western culture. 


\section{Application Measures of English Movies in College English Listening Teaching}

\section{Theme Choice}

As the saying goes, "The right choice makes a bright future". The reason why college English listening teaching introduces English movies is that teachers want to bring foreign advanced ideas and relaxed atmosphere of learning into the classroom. Therefore, the choice of introduction of English movies is very important. The reference of foreign culture should be to take its essence; teachers should be strictly, and strive to teaching materials before the selection of subject matter. Only in this way can we ensure English films on college English listening are helpful. In the practice of college English listening teaching, some hit movie is very efficient, because this will precisely meet young people' chase fashion psychological understanding of these films, which will let students be full of yearning in English, thus English movies are bound to have great help to student's literary attainments and hearing level.

\section{Selection of Original Material}

At present, most students can obtain different types of English resources through the Internet, but many English resources are not from native English. In order to better reflect the help of English movies to college students' listening, the original film must be full of authentic foreign language. Thus the students can understand the characteristics of foreign culture.

\section{The Choice of English Movies Vary From Person to Person}

English movies should be used in the analysis of the dialectical thinking in classroom, not all English movies are suitable for teaching, and not all of the original films reflect the real foreign culture. The process of teachers choosing subject matters is also a kind of a kind of discrimination of culture, because English teaching is not only language teaching, the more important is a kind of cultural education. Only by achieving the combination of culture and language teaching, can it be called successful language teaching, and reach a higher level in the way of English learning.

\section{Conclusion}

The reform of college English teaching must be combined with the practical application of the teaching resources and students' English ability, and the emphasis on the reform of English teaching in the training of students' listening and speaking ability. English teaching needs the method of modern teaching and scientific teaching. To ensure that, each student can integrate into the classroom teaching, in the process of learning to achieve their own rapid progress and full development. English movies gain rapid attention from university English listening teaching with its characteristics and advantages of the illustrations and vivid images. English movies reproduce the rich international culture, extend the students' knowledge, break the resources limit of traditional listening teaching, and stimulate the students' thirst for knowledge, which has a important role in improving the teaching level of college English listening.

\section{References}

Aida, Y. (1994). Examination of Horwitz and Copes construct of foreign anxiety: The case of students of Japanese. The Modem Language Journal, 78(13), 154-168.

Arnold, J. (2000). Affect in language learning. Beijing: Foreign Language Teaching and Research Press. 
Baldry, A., \& Thibault, P. J. (2006). Mutimodal transcription and text analysis (pp. 21-25). London: Equinox.

Harmer, J. (2003). The practice of English language teaching. Beijing: World Affairs Press.

Hill, B. (1991). Making the most of satellites and interactive video. London: Information Language Teaching and Research.

Kolb, B., \& Whishaw, I. Q. (2003). Fundamentals of human neuropsychology. New York: Worth Publishers.

Van Leeuwen, T. (2005). Introducing social semiotics (pp. 256-258). London: Routledge.

XIAO, L. H. (2008). Effect factors and coping strategies of university English listening teaching. Journal of Shenyang Normal University, 33(21), 57-59. 